\title{
The prevalence of human cytomegalovirus DNA in gliomas of Brazilian patients
}

\author{
Renata Fragelli Fonseca', Marcia Tie Kawamura1, José Antônio Oliveira², \\ Anselmo Teixeira ${ }^{2}$, Gilda Alves ${ }^{3 /+}$, Maria da Glória da Costa Carvalho ${ }^{1}$
}
'Laboratório de Controle da Expressão Gênica, Instituto de Biofísica Carlos Chagas Filho, Universidade Federal do Rio de Janeiro, Rio de Janeiro, RJ, Brasil ${ }^{2}$ Serviço de Neurocirurgia ${ }^{3}$ Laboratório de Genética Aplicada, Serviço de Hematologia, Instituto Nacional de Câncer, Rio de Janeiro, RJ, Brasil

Members of the Herpesviridae family have been implicated in a number of tumours in humans. At least 75\% of the human population has had contact with cytomegalovirus (HCMV). In this work, we screened 75 Brazilian glioma biopsies for the presence of HCMV DNA sequences. HCMV DNA was detected in $36 \%$ (27/75) of the biopsies. It is possible that HCMV could be a co-factor in the evolution of brain tumours.

Key words: brain tumour - glioma - cytomegalovirus - HCMV

Gliomas are the most common primary brain tumour (Louis 2007) and glioblastomas (GBM) are the most aggressive type of glioma. The aetiology of these brain tumours has not been elucidated.

Viral infections are responsible for approximately $15 \%$ of cancers worldwide (Young 1998). One important herpesvirus is human cytomegalovirus (HCMV), which is carried by the majority of the population worldwide. HCMV is a leading cause of opportunistic and congenital disease (Slobedman \& Mocarski 1999) and it is the most frequent infectious cause of developmental disorders of the central nervous system (CNS) in humans. Although primary and reactivated infections are frequently asymptomatic in healthy individuals, HCMV infections are the major cause of illness and death in immunecompromised patients, including acquired immune deficiency syndrome patients and allograft transplant recipients (Brytting et al. 1992). Recently, it was shown that HCMV plays a role in malignant gliomas. In this paper, we determined the prevalence of HCMV in primary human brain tumours. To our knowledge, this is the first report of HCMV DNA in brain tumours in the Brazilian population.

A total of 75 primary glioma biopsies and six nonglial brain tumours were obtained at the time of surgery and prior to any clinical therapy at National Cancer Institute (INCA), Rio de Janeiro, Brazil, between 19972001. The brain tumour tissues were taken isolated by stereotactic biopsy, snap-frozen in liquid nitrogen and stored at $-70^{\circ} \mathrm{C}$ until DNA extraction. Each sample was subjected to proteinase $\mathrm{K}(100 \mu \mathrm{g} / \mathrm{mL})$ digestion, followed by phenol:chloroform:isoamyl alcohol (25:24:1) extraction and precipitation with ethanol. DNA samples were stored at $-20^{\circ} \mathrm{C}$ for molecular analysis. HCMV DNA detection was performed as previously described

+ Corresponding author: gbrown@inca.gov.br

Received 28 February 2012

Accepted 29 June 2012
(Demmler et al. 1988), with the amplification of a $400 \mathrm{bp}$ DNA product of the tegument protein pp65. The primer sequences used (Research Genetics) were CACCTGTCACCGCTGCTATATTTGC and CACCACGCAGCGGCCCTTGATGTTT. This work was approved by the Ethical Board of INCA, with the registration 35/02. Informed consent was obtained from all patients.

The cohort was composed of 40 males and 35 females; 25 patients were children (under 21 years old) and 50 were adults. The clinical characteristics of the patients enrolled in this study and the HCMV prevalence are summarised in Supplementary data. HCMV DNA was detected in $27 / 75$ (36\%) biopsies belonging to diverse histological types. The presence of HCMV DNA was also assessed in non-glial brain tumours (1 neurilemma, 2 non-Hodgkin's lymphomas, 2 pituitary adenomas and 1 cortical dysplasia), all of which negative for HCMV DNA. These results are not included in Supplementary data. Examples of the polymerase chain reaction $(\mathrm{PCR})$ results are shown in Figure.

The statistical analysis of parameters such as age, histological classification/grade and tumour localisation vs. the detection of positive HCMV DNA did not show any significant association. The global five-year survival was $57 \%$ for patients with grade I and II astrocytomas (low grade) and 18\% for patients with grade III astrocytomas and GBMs (high grade). The difference between the global survival for low-grade and high-grade astrocytomas was statistically significant ( $p=0.004$ by Wilcoxon Test) and consistent with expectations based on the histological classification and grade. The survival of HCMV DNA-positive patients was similar to HCMV DNA-negative patients.

The role of HCMV in brain tumour development has been a matter of debate for many years. Cobbs et al. (2002) reported an association between HCMV and malignant gliomas by immunohistochemistry (IMH) using an anti-IE1-72 antibody. The HCMV-positive tumours in that study included 22/22 GBMs, one/one grade III astrocytomas and four/four grade II astrocytomas. In contrast, zero/22 control tissues (meningioma, stroke 
and Alzheimer's disease) were negative. To confirm their positive results, Cobbs et al. (2002) also used two HCMV antibodies (anti-pp65 and anti-p52/76KDa) in IMH assays, an in situ hybridisation (ISH) assay with a probe specific for an early gene and electron microscopy-based IMH with an anti-pp65 antibody.

In contrast, Sabatier et al. (2005) screened 132 CNS tumours, including 97 GBMs, by IMH (anti-IE1 monoclonal antibody) and ISH with tissue microarrays and frozen sections and found rare astrocyte-like cells staining positive for HCMV in only 10 cases of GBM and questionable staining of rare cells in one case. This result suggested that none of the CNS tumours contained HCMV genomes and/or proteins in a significant proportion of tumour cells. In another work, Lau et al. (2005) investigated HCMV in a group of 22 brain tumours of various histological types and grades ( 8 GBMs, 6 grade III astrocytomas, 3 grade II astrocytomas, 2 oligodendrogliomas and 3 ependymomas) and controls (4 normal brain tissue samples and other tumours) by PCR, ISH with a probe complementary to HCMV early gene mRNA and IMH. None of the brain tumours or normal brain tissue tested demonstrated the expression of the HCMV proteins pp65 or p52 by IMH. In addition, no HCMV RNA or DNA was detected in these cases by ISH and PCR. These findings suggested that HCMV was not significantly associated with brain tumours. However, more studies investigating the importance of HCMV in brain tumours have emerged.

Mitchell et al. (2008) detected HCMV in the tumours and peripheral blood of patients diagnosed with GBM and normal controls using IMH, ISH and PCR of viral DNA. They showed that a high percentage $(>90 \%)$ of GBM tumours were associated with HCMV nucleic acids and proteins. Furthermore, $80 \%$ of the patients had detectable HCMV DNA in their peripheral blood. Lucas et al. (2011) performed IMH of HCMV proteins on 49 paraffin-embedded tissue sections of GBM tumours, the largest series reported to date. They confirmed the presence of HCMV pp65 in 25/49 (51\%) and IE1 in eight/49 $(16 \%)$ of these tumours.

The contradictory reports about the importance of HCMV in brain tumours are not easily explained. One possible explanation is that these investigations were performed in different populations. If this hypothesis is true, the information about the prevalence of HCMV in glioma patients in our study $(27 / 75,36 \%)$ might be particularly interesting because the Brazilian genetic background is unique due to its complex racial mixture.

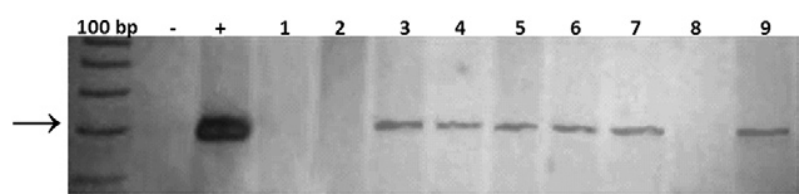

Polyacrylamide gel electrophoresis gel $8 \%$, silver stained, showing polymerase chain reaction products of human cytomegalovirus. Lanes 1, 2, 8: tumours' DNAs without amplification; 3-7, 9: tumours' DNAs with amplification. Arrow indicates 400 bp band. Negative and positive controls are indicated.
Little is known about the aetiology (genetic background $\times$ environment) of brain tumours, especially in the Brazilian population. Linhares et al. (1989) showed differences in the HCMV serological status of $616 \mathrm{Bra}-$ zilians and 399 Japanese immigrants living in Northeast Brazil. The patient sera were screened for IgG antibodies against HCMV by ELISA. The overall prevalence of HCMV antibodies was higher in the Japanese population $(83.7 \%)$ than in the Brazilian population $(69.8 \%)$. These findings are consistent with our results, in which the prevalence of positivity for HCMV DNA was lower than in other populations. Nevertheless, we cannot rule out that differences in the methodological approaches influenced the overall results.

In view of these results, HCMV vaccination and/ or other anti-HCMV drugs (Sampson \& Mitchell 2011) should be considered in brain tumour therapy.

\section{ACKNOWLEDGEMENTS}

To Marcelo Soares Mota, for technical assistance, to all members of the Neurosurgery Service, and to CNPq, for scholarship of the student involved in this work.

\section{REFERENCES}

Brytting M, Xu W, Wahren B, Sundquist V-A 1992. Cytomegalovirus DNA detection in sera from patients with active cytomegalovirus infections. J Clin Microbiol 30: 1937-1941.

Cobbs CS, Harkins L, Samanta M, Gillepsie Y, Bharara S, King PH, Nabors BN, Cobbs, CG, Britt WJ 2002. Human cytomegalovirus infection and expression in human malignant glioma. Cancer Res 62: 3347-3350.

Demmler GJ, Buffone GJ, Schimbor CM, May RA 1988. Detection of cytomegalovirus in urine from newborns by using polymerase chain reaction DNA amplification. J Infect Dis 158: 1177-1184.

Lau SK, Chen YY, Chen WG, Diamond DJ, Mamelak AN, Zaia JA, Weiss LM 2005. Lack of association of cytomegalovirus with human brain tumors. Mod Pathol 18: 838-843.

Linhares MI, de Andrade GP, Tateno S, Eizuru Y, Minamishima Y 1989. Prevalence of cytomegalovirus antibodies in Brazilian and Japanese populations in the North-East of Brazil. Microbiol Immunol 33: 975-980.

Louis DN, Ohgaki H, Wiestler OD, Cavenee WK, Burger PC, Jouvet A, Scheithauer BW, Kleihues P 2007. The 2007 WHO classification of tumours of the central nervous system. Acta Neuropathol 114: 97-109. Erratum in 114: 547.

Lucas KG, Bao L, Bruggeman R, Dunham K, Specht C 2011. The detection of CMV pp65 and IE1 in glioblastoma multiforme. J Neurooncol 103: 231-238.

Mitchell DA, Xie W, Schmittling R, Learn C, Friedman A, McLendon RE, Sampson JH 2008. Sensitive detection of human cytomegalovirus in tumors and peripheral blood of patients diagnosed with glioblastoma. Neuro Oncol 10: 10-18.

Sabatier J, Uro-Coste E, Pommepuy I, Labrousse F, Allart S, Trémoulet M, Delisle MB, Brousset P 2005. Detection of human cytomegalovirus genome and gene products in central nervous system tumours. Br J Cancer 92: 747-750.

Sampson JH, Mitchell DA 2011. Is cytomegalovirus a therapeutic target in glioblastoma? Clin Cancer Res 17: 4619-4621.

Slobedman B, Mocarski ES 1999. Quantitation analysis of latent human cytomegalovirus. J Virol 73: 4806-4812.

Young LS 1998. Viruses and human cancer, Bios Scientific Publishers, Oxford, $200 \mathrm{pp}$. 
Clinical characteristics of the patients included in this study and human cytomegalovirus (HCMV) DNA prevalence

\begin{tabular}{|c|c|c|c|c|c|}
\hline Case & Age (years)/sex & Histological type and grade ${ }^{a}$ & Tumour localization & HCMV & $\begin{array}{l}\text { Survival } \\
\text { (month) }\end{array}$ \\
\hline 1 & $72 / \mathrm{F}$ & Glioblastoma & Frontal lobe & + & 24 \\
\hline 2 & $8 / \mathrm{M}$ & Oligoastrocytoma & Temporal lobe & + & Alive \\
\hline 3 & $28 / \mathrm{F}$ & Astrocytoma II & Mesencephalic and diencephalic & + & Alive \\
\hline 4 & $15 / \mathrm{M}$ & Astrocytoma II & IV ventricle & + & 9 \\
\hline 5 & $42 / \mathrm{M}$ & Astrocytoma III & Frontal lobe & + & 2 \\
\hline 6 & $45 / \mathrm{F}$ & Astrocytoma II & Frontal lobe & - & 156 \\
\hline 7 & $48 / \mathrm{F}$ & Oligodendroglioma & Frontotemporal & + & Alive \\
\hline 8 & $58 / \mathrm{M}$ & Glioblastoma & Temporal lobe & + & 6 \\
\hline 9 & 6/M & Ependymoma & IV ventricle & - & 60 \\
\hline 10 & $4 / \mathrm{F}$ & Astrocytoma II & Supratentorial & - & 1 \\
\hline 11 & $33 / \mathrm{F}$ & Astrocytoma II & Frontal lobe & - & Alive \\
\hline 12 & $68 / \mathrm{F}$ & Astrocytoma III & Supratentorial & - & 3 \\
\hline 13 & $49 / F$ & Astrocytoma II & Thalamic & + & 6 \\
\hline 14 & $83 / \mathrm{M}$ & Astrocytoma III & Supratentorial & - & 2 \\
\hline 15 & $74 / \mathrm{F}$ & Astrocytoma III & Frontotemporal & + & 3 \\
\hline 16 & $35 / \mathrm{F}$ & Astrocytoma II & Thalamic & + & 18 \\
\hline 17 & $72 / \mathrm{M}$ & Glioblastoma & Frontal lobe & - & 2 \\
\hline 18 & $51 / \mathrm{M}$ & Astrocytoma III & Parietal lobe & - & 2 \\
\hline 19 & $40 / \mathrm{M}$ & Astrocytoma II & Corpus callosum & + & 2 \\
\hline 20 & $50 / \mathrm{M}$ & Glioblastoma & Frontal & + & 3 \\
\hline 21 & $9 / \mathrm{F}$ & Astrocytoma I & Cerebellar vermis & + & Alive \\
\hline 22 & $31 / \mathrm{M}$ & Glioblastoma & Brain stem & + & 10 \\
\hline 23 & $55 / \mathrm{F}$ & Glioblastoma & Lateral ventricle & - & 1 \\
\hline 24 & $44 / F$ & Astrocytoma II & Frontal lobe & - & Alive \\
\hline 25 & $52 / \mathrm{F}$ & Ependymoma & Supratentorial & + & 2 \\
\hline 26 & $70 / \mathrm{M}$ & Glioblastoma & Parietal lobe & - & 2 \\
\hline 27 & $38 / \mathrm{F}$ & Astrocytoma II & Frontotemporal & - & 24 \\
\hline 28 & $66 / \mathrm{M}$ & Glioblastoma & Supratentorial & - & 1 \\
\hline 29 & $70 / \mathrm{M}$ & Glioblastoma & Frontotemporal & - & 1 \\
\hline 30 & $1 / \mathrm{M}$ & Astrocytoma III & Thalamic & - & 7 \\
\hline 31 & $15 / F$ & Astrocytoma I & Diencephalic & - & Alive \\
\hline 32 & $66 / \mathrm{M}$ & Glioblastoma & Frontal lobe & + & 11 \\
\hline 33 & $51 / \mathrm{F}$ & Glioblastoma & Supratentorial & - & 3 \\
\hline 34 & $40 / \mathrm{F}$ & Astrocytoma II & Supratentorial & + & 86 \\
\hline 35 & $10 / \mathrm{M}$ & Astrocytoma I & Cerebellar & + & Alive \\
\hline 36 & $37 / \mathrm{F}$ & Astrocytoma II & Temporal lobe & + & 62 \\
\hline 37 & $36 / F$ & Ependymoma & Cauda equina & + & Alive \\
\hline 38 & $64 / F$ & Oligodendroglioma & Frontal lobe & - & 64 \\
\hline 39 & $4 / \mathrm{M}$ & Astrocytoma II & Supratentorial & + & 1 \\
\hline 40 & $5 / \mathrm{M}$ & Astrocytoma II & Frontal lobe & - & Alive \\
\hline 41 & $20 / \mathrm{M}$ & Astrocytoma II & Temporal lobe & - & Alive \\
\hline 42 & $10 / \mathrm{M}$ & Ependymoma & IV ventricle & - & 24 \\
\hline 43 & $34 / F$ & Astrocytoma II & Frontotemporal & - & Alive \\
\hline 44 & $8 / \mathrm{F}$ & Astrocytoma II & Thalamic & - & 27 \\
\hline 45 & $35 / \mathrm{M}$ & Astrocytoma III & Frontal lobe & - & 46 \\
\hline 46 & $6 / \mathrm{F}$ & Astrocytoma I & Cerebellar vermis & + & Alive \\
\hline 47 & $28 / \mathrm{M}$ & Astrocytoma I & Frontal lobe & - & Alive \\
\hline 48 & $14 / \mathrm{F}$ & Astrocytoma III & Brain stem & + & Alive \\
\hline 49 & $78 / \mathrm{M}$ & Glioblastoma & Temporal lobe & + & 3 \\
\hline 50 & $57 / \mathrm{M}$ & Astrocytoma II & $\begin{array}{l}\text { Right frontal lobe and two } \\
\text { lesions at left parietal lobe }\end{array}$ & + & 1 \\
\hline
\end{tabular}




\begin{tabular}{|c|c|c|c|c|c|}
\hline Case & Age (years)/sex & Histological type and grade ${ }^{a}$ & Tumour localization & HCMV & $\begin{array}{l}\text { Survival } \\
\text { (month) }\end{array}$ \\
\hline 51 & 9/M & Astrocytoma II & Thalamic & - & Alive \\
\hline 52 & $17 / \mathrm{M}$ & Glioblastoma & Parietal lobe & - & 92 \\
\hline 53 & $36 / \mathrm{F}$ & Astrocytoma III & Parietal lobe & - & Alive \\
\hline 54 & $10 / \mathrm{M}$ & Astrocytoma III & Cerebral ventricle & + & Alive \\
\hline 55 & $38 / \mathrm{M}$ & Glioblastoma & Supratentorial & - & 5 \\
\hline 56 & $49 / \mathrm{F}$ & Astrocytoma I & Frontal lobe & - & 1 \\
\hline 57 & $63 / \mathrm{F}$ & Oligoastrocytoma & Temporal lobe & - & 1 \\
\hline 58 & $31 / \mathrm{M}$ & Astrocytoma II & Frontal lobe & - & Alive \\
\hline 59 & $32 / \mathrm{M}$ & Astrocytoma II & Brain stem & - & 2 \\
\hline 60 & $29 / \mathrm{M}$ & Astrocytoma III & Thalamic & - & 1 \\
\hline 61 & $38 / \mathrm{F}$ & Astrocytoma III & Frontal lobe & - & Alive \\
\hline 62 & $34 / \mathrm{M}$ & Astrocytoma II & Temporal lobe & - & Alive \\
\hline 63 & $74 / \mathrm{M}$ & Astrocytoma III & Parietal lobe & + & 11 \\
\hline 64 & $12 / \mathrm{M}$ & Astrocytoma III & Thalamic & - & 7 \\
\hline 65 & $71 / \mathrm{F}$ & Glioblastoma & Occipital lobe & - & 7 \\
\hline 66 & $32 / \mathrm{F}$ & Astrocytoma III & Parietal lobe & - & 39 \\
\hline 67 & $11 / \mathrm{M}$ & Ependymoma & Temporal lobe & - & Alive \\
\hline 68 & $66 / \mathrm{F}$ & Glioblastoma & Supratentorial & - & 1 \\
\hline 69 & $2 / \mathrm{F}$ & Astrocytoma II & Parietal lobe & - & Alive \\
\hline 70 & $53 / \mathrm{F}$ & Glioblastoma & Frontal lobe & - & 6 \\
\hline 71 & $54 / \mathrm{F}$ & Glioblastoma & Frontotemporal & - & 1 \\
\hline 72 & 9/M & Astrocytoma III & Brain stem & - & 20 \\
\hline 73 & $5 / \mathrm{M}$ & Astrocytoma II & Brain stem & - & Alive \\
\hline 74 & $12 / \mathrm{F}$ & Astrocytoma II & Parietal lobe & - & 12 \\
\hline 75 & $11 / \mathrm{M}$ & Astrocytoma I & Temporal lobe & - & Alive \\
\hline
\end{tabular}

$a$ : by World Health Organization; F: female; M: male. 